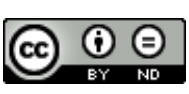

AGNIESZKA ROSA, KAMILA SIUDA (Uniwersytet Mikołaja Kopernika w Toruniu)

\title{
ANTROPOLOGIA KULTUROWA I METODY ETNOGRAFICZNE W ARCHIWISTYCE
}

\section{Słowa kluczowe}

antropologizowanie archiwistyki; archiwozofia; metody etnograficzne; obserwacja uczestnicząca; egodokumentalność

Agnieszka Rosa. Od 2010 r. pracuje na stanowisku adiunkta w Instytucie Historii i Archiwistyki UMK. Jej zainteresowania badawcze obejmują: archiwistykę, problemy edukacji archiwistów, kształcenie użytkowników archiwów, archiwizację Internetu, komputeryzację archiwów, teorię egodokumentu. Jest autorką książki Funkcja edukacyjna archiwów, Warszawa 2012 i współautorką książki Butlerio kelionès i Italija ir Voketija 1779-1780 metais dienoraštis, Wilno 2013, współredaktorką serii wydawniczej „Toruńskie konfrontacje archiwalne” (t. 1-5 ) i kilku monografii, sekretarzem redakcji czasopisma „Archiwa - Kancelarie - Zbiory”, a także pomysłodawcą i założycielem Forum Edukatorów Archiwalnych. Jest zastępcą przewodniczącej zarządu Sekcji Edukacji Archiwalnej SAP, członkiem PPTH i TNT.

E-mail: arosa@umk.pl

ORCID ID: 0000-0002-8560-1387

Kamila Siuda. Magister etnologii i antropologii kulturowej oraz archiwistyki i zarządzania dokumentacją, obecnie doktorantka na Wydziale Nauk Historycznych UMK w Toruniu. Pod opieką dr. hab. Waldemara Chorążyczewskiego, prof. UMK przygotowuje pracę doktorską na temat archiwów etnograficznych w Polsce. Jej zainteresowania badawcze obejmują: archiwistykę, antropologię kulturową, teorię egodokumentu. Należy do SAP, Polskiego Towarzystwa Ludoznawczego, Forum Edukatorów Archiwalnych i Towarzystwa Miłośników Ziemi Świeckiej.

E-mail: kamila.s@doktorant.umk.pl 


\section{Keywords}

anthropology in archival science; archivosophy; ethnographic methods; participatory observation; egodocument

\section{Streszczenie}

Celem artykułu jest ukazanie możliwości prowadzenia w archiwistyce badań z wykorzystaniem metod etnograficznych, metod jakościowych pozwalających na poznanie zależności między człowiekiem a procesem, w który został wmontowany, z uwzględnieniem wszystkich relacji jakie zachodzą między członkami badanej grupy, ludźmi a systemem, dokumentem i informacją, w kontekście powstawania i zarządzania dokumentacją (w tym także archiwaliami). Artykuł składa się z dwóch części. W pierwszej przedstawione zostały wybrane badania $\mathrm{z}$ wykorzystaniem metod etnograficznych $\mathrm{w}$ archiwistyce, opublikowane na łamach literatury anglojęzycznej. W drugiej części zamieszone zostało podsumowanie i ocena dorobku polskiego piśmiennictwa archiwalnego zaliczanego do nurtu określanego jako podejście antropologiczne w archiwistyce (lub też antropologizowanie archiwistyki, lub archiwozofia), a także przedstawione nieliczne przykłady polskich badań z wykorzystaniem metod etnograficznych w archiwistyce.

\section{Summary}

\section{Cultural anthropology and ethnographic methods in archival science}

The aim of the article is to show possibilities of conducting research in archival science using ethnographic methods, quality methods that allow to recognise connections between humans and a process they got set into, using all relations between members of the group studied, people and the system, records and information, in the context of creating and managing records (including archival materials). The article consists of two parts. The first part presents chosen research using ethnographic methods in archival science, that were published in English literature. The second part is a summary and assessment of the Polish archival literary output, that is part of a trend called anthropological orientation in archival science (or archivosophy), and also presentation of few Polish studies using ethnographic methods in archival science.

H umanistyczny „zwrot kulturowy”1 obserwować można było już w latach 60. i 70. XX w. Wiązał się on z recepcją idei wywodzącej się z antropologii, która pojęcie kultury stawia w centrum swojego analitycznego słownika.

1 Zwrot w kulturze to nowe idee zmieniające dotychczasowy sposób ich badania. Tym samym przez 'zwrot kulturowy' rozumiemy wszystkie perspektywy badawcze, które z kultury czynią główny element rozważań, zob. np. W. J. Burszta, M. Januszkiewicz, Stowo wstępne: kłopot zwany kulturoznawstwem, [w:] Kulturo-znawstwo: dyscyplina bez dyscypliny?, red. W.J. Burszta, M. Januszkiewicz, Warszawa 2010. 
Stąd pierwotnie, wprost lub pośrednio, czerpano wzorce do budowy nowych dyskursów humanistyki. Nie powinno więc dziwić, że w hybrydyzujących się tożsamościach dyscyplin humanistycznych, terminy takie jak „antropologia” czy „antropologiczny” są odmieniane przez wszystkie przypadki, a zwyczaj odwoływania się do antropologii wszedł do kanonu gestów czynionych przez wielu badaczy ${ }^{2}$.

Zjawisko określane mianem antropologizacji humanistyki to m.in. ruch zmierzający w stronę ogólnego przeformułowania granic tradycyjnych dyscyplin, ruch wiodący do konstytuowania się nowych paradygmatów badań przedmiotowych. Zarówno w Polsce, jak i na świecie, kwestia ta nie ominęła archiwistyki ${ }^{3}$. Jednak po kilkunastu latach obserwacji rozwoju tej tendencji badawczej na naszym gruncie, odczuć można niedostrzeganie w środowisku wszystkich możliwości jakie ona daje.

Przykłady literatury anglosaskiej i polskiej podpowiadają jak można rozwinąć indywidualną optykę badawczą, która sprowadza się do przyjęcia wobec przedmiotu badań, jaką jest szeroko rozumiana archiwistyka (razem z jej przedmiotem badań - archiwami i archiwaliami oraz relacjami jakie między tymi elementami zachodzą), perspektywy określanej mianem antropologicznej.

Humanistów, a w tym archiwistów, przestało satysfakcjonować poszukiwanie obiektywnej prawdy ${ }^{4}$. Dziś ograniczanie się do odpowiedzi na pytanie jak coś działa, bądź sporządzenia samego opisu, przy mnogości procesów związanych z dokumentacją i obiegiem informacji jest niewystarczające. By podjąć próby zrozumienia tych wielowarstwowych często mechanizmów, potrzebne są dodatkowe pytania i metody badawcze, które ułatwią zrozumienie skomplikowanego splotu ludzi, ich wytworów, technologii, praktyki i polityki. Z pomocą przychodzi między innymi antropologia/etnologia wraz ze swoimi metodami badawczymi. Antropologia jako nauka dąży do zrozumienia społeczeństwa w dokładny i systematyczny sposób, szuka odpowiedzi na pytania o przejawy życia społecznego i organizacyjnego. Badania etnograficzne (obejmujące m.in. poszerzoną obserwację, wywiad i analizę dokumentacji) to próby poznania poszczególnych grup ludzi i ich reprezentacji. Metody badawcze to zazwyczaj

2 Zob. np. A. Kuper, Kultura. Model antropologiczny, Wydawnictwo Uniwersytetu Jagiellońskiego, Kraków 2005.

3 Zob. A. Rosa, Archiwa między historiq i pamięcią. Antropologizowanie archiwistyki, „Archiwa - Kancelarie - Zbiory”, t. 2, 2008, s. 99-127; D. Magier, Czas archiwozofii, [w:] Toruńskie konfrontacje archiwalne, t. 2: Teoria archiwalna wczoraj-dziś - jutro, red. W. Chorążyczewski, A. Rosa, Toruń 2011, s. 9-20.

4 A. Rosa, Archiwa między historia i pamięcia, s. 99-127. 
specyficznie połączone techniki pozyskiwania danych. Etnografia uważana jest również za rodzaj strategii badawczej, która pozwala zrozumieć ludzkość, poznać różnice, które czynią nas tym, kim jesteśmy jako ludzie ${ }^{5}$. Materiał w tych badaniach zbierany jest w naturalnym środowisku badanych, których stara się uchwycić w ich codziennych czynnościach, a w które włączony jest także badacz, ale bez stawiania hipotez. Cechami tego badania jest realizm, odzwierciedlenie i przedstawienie. Nie ma jednej techniki zbierania materiałów. Pozyskać go można zarówno podczas nieformalnej rozmowy, w trakcie wywiadu etnograficznego, jak i w czasie obserwacji uczestniczącej czy poprzez analizę dokumentów. Etnografię należy traktować jako produkt badań jakim jest raport badawczy. Składa się na niego i opis analityczny, i próby rekonstrukcji całych kulturowych scen i obrazów. W badaniu etnograficznym najważniejsze jest, by opis dokonywano z punktu widzenia członków opisywanej wspólnoty. Tym samym celem badań jakościowych o charakterze etnograficznym jest ukazanie zjawiska w jego osobliwym kształcie. Jest to rodzaj studiów kulturowych, w których strategia badawcza opiera się na pozycji całkowitej niewiedzy, a zadaniem badacza jest poznanie języka - kodu kulturowego badanej społeczności oraz głównych zjawisk obyczajowych. Co ważne, w badaniu etnograficznym, zwanym również badaniem interpretacyjnym, postępowanie badawcze nie ma sztywnego planu działania. Nie stosuje się żadnych kategorii tworzonych w celu interpretacji tego, co ludzie mówią, a analiza danych, to głównie interpretacja znaczeń i funkcjonowania ${ }^{6}$.

Przedstawiciele zagranicznych archiwalnych środowisk naukowych dostrzegając możliwości badań z zastosowaniem metod etnograficznych postanowili rozszerzyć optykę widzenia pewnych procesów, które do tej pory badane były w klasyczny sposób. Wyszli w teren, do archiwum lub instytucji wytwarzającej dokumentację, i korzystając z metody etnograficznej, rozpoczęli badania mające na celu poznanie zależności pomiędzy człowiekiem (który zawsze jest w centrum tych badań) a procesem, w który został wmontowany, ze wszystkimi relacjami między członkami badanej grupy, ludźmi a systemem, dokumentem i informacją.

Rozkwit zainteresowań metodą etnograficzną w archiwistyce dostrzec można w opublikowanych wynikach badań na łamach zagranicznych czasopism archiwistycznych oraz w pracach zbiorowych i monografiach począwszy od 2003 r., i te głównie w niniejszym artykule będą przytaczane. Aczkolwiek zainteresowanie

5 B. Borowska-Beszta, Etnografia dla terapeutów (pedagogów specjalnych) - szkice metodologiczne, Kraków 2005, s. 42.

6 Tamże, s. 43-45. 
antropologów archiwami i refleksja nad nimi sięga już lat 70. ubiegłego wieku, kiedy to historyczka i etnolożka Rolande Bonnain-Dulon rozpoczęła eksploracje francuskich archiwów w celu poszerzenia bazy materiałów źródłowych dot. pożywienia, a swe obserwacje opublikowała w 2003 r.7 Według autorów tych badań, etnologia w archiwistyce może działać na kilku obszarach. Po pierwsze, dzięki tej metodzie można badać funkcjonowanie instytucji jaką jest archiwum - laboratorium (pracowników, ich wzajemne stosunki, motywy funkcjonowania). Tu możliwa jest choćby analiza realizacji przyjęcia międzynarodowych standardów, rozporządzeń, ich odbioru w konkretnym kręgu kulturowym, oddziaływaniu, adaptacji itd. Drugim tropem jest badanie problemu, z którym muszą zmierzyć się archiwiści pracujący w danej jednostce (np. konserwacja, digitalizacja, retrokonwersja). Trzecią możliwą ścieżką jest badanie samego dokumentu w archiwach. Jego treści, ale tak by poznać kulturowe tło powstania dokumentu wraz z zapisanymi w nim historiami określonych bohaterów - w Polsce rozumianej jako historia mentalności, czy badania egodokumentalne ${ }^{8}$.

Na Uniwersytecie Indiana w Bloomington przebadano funkcjonowanie tzw. laboratoriów badawczych (coś w rodzaju żywych archiwów naukowych) miejsc wytwarzania i przechowywania dokumentacji z prowadzonych badań naukowych/laboratoryjnych, analiz, miejsc spotkań naukowców i wymiany myśli. Informatolożka i socjolożka Kalpana Shankar ${ }^{9}$ podjęła się próby zbadania takiego laboratorium jako organizacji przechowywania informacji i skrzyżowania praktyki naukowej z rodzajami dokumentów, jakie tworzą i używają naukowcy. Badaczka, by bliżej poznać miejsce i ludzi tworzących laboratorium spędziła w nim osiem miesięcy, prowadząc dziennik terenowy. Było to niezbędne do dalszej analizy i sporządzenia kwestionariusza pytań, które finalnie zadała w czasie przeprowadzanych wywiadów z pracownikami. Celem tych rozmów było zrozumienie, jak osoby w grupie postrzegają i wyjaśniają ich własne zachowania,

7 R. Bonnain-Dulon, De l'apprentissage des archives pour une ethnologue (1974-2003), „Ateliers du LESC”, nr 32, 2008, https://doi.org/10.4000/ateliers.2732 (dostęp 09.07.2018).

8 Zob. np. W. Chorążyczewski, A. Rosa, Egodokumenty - egodokumentalność - analiza egodokumentalna - spuścizna egodokumentalna, [w:] Egodokumenty, tradycje historiograficzne i perspektywy badawcze, red. W. Chorążyczewski, A. Pacevicius, S. Roszak, Toruń 2015, s. 11-21; A. Rosa, K. Siuda, Analiza egodokumentalna pamiętników archiwistów jako przyczynek do poznania mentalności określonej grupy zawodowej, [w:] Toruńskie konfrontacje archiwalne, t. 6: Pogranicza archiwistyki, red. W. Chorążyczewski, A. Rosa, Toruń 2019 [w druku].

9 K. Shankar, Recordkeeping in the Production of Scientific Knowledge: An Ethnographic Study, „Archival Science”, 2004, nr 4, s. 367-382. 
jakie są ich własne praktyki przechowywania dokumentacji, jak myślą o swoich relacjach z innymi członkami grupy i ich zawodzie. Następnym etapem była analiza wytworzonych dokumentów. Te trzy elementy Kaphala połączyła analizując je przy pomocy programu badań jakościowych i „otwartego kodowania”. Badania, jak sama przyznała, choć czaso- i pracochłonne, nasunęły kilka ważnych wniosków. Jednym z nich było to, że potrzebnych jest więcej pogłębionych studiów nad naturą dokumentacji i środowiskiem, w których są one tworzone. Łączy się z tym potrzeba zrozumienia technologii i standardów do tworzenia opisu dokumentu. Drugą było samo użycie dokumentacji. W obrębie tego zagadnienia mieściła się natura pamięci i jej wykorzystania, a także celów tworzenia dokładnych rejestrów i ich wypełniania. Znamiona charakteru twórcy, odciśnięte w dokumencie (pozycja zawodowa, odpowiedzialność, przyzwyczajenia, cechy charakteru, osobowość, mentalność), to także część tej analizy. Trzecim ważnym zagadnieniem według autorki było samo osadzenie laboratorium w szerszym kontekście (prawnym, kulturowym, instytucjonalnym i zawodowym), czyli jak miejsce wpływa na tworzone materiały i ich wykorzystanie. To badanie interakcji z obszarami (rodzaj zapisu, intencjonalności zastosowania oraz jak inne czynniki środowiska wpływają na te praktyki) ukazały wcześniej niedostrzegane procesy. Metoda etnograficzna rozszerzyła wachlarz pytań. Dla autorki wiedza o tym, dlaczego powstał dany dokument, nie forma zapisu, a sposób ewidencji stały się kluczem do poznania tego, co nie uświadomione, a co stało się częścią bezrefleksyjnych zachowań pracowników laboratorium ${ }^{10}$.

Bibliolożka i etnolożka Danielle Copper ${ }^{11}$ z Kanady w interesujący sposób przedstawiła działanie archiwum prywatnego mniejszości seksualnych. W badaniach skupiła się na obserwacji działań dokumentacyjnych, gromadzeniu dokumentacji, stosunku emocjonalnego do niej, ale także koncepcji i odbiorze prywatnych archiwów w przestrzeni publicznej i roli archiwistów-praktyków w kształtowaniu tego zasobu. Badania wykazały przede wszystkim problem kwestionowania archiwów prywatnych przez postrzeganie ich jako „mało poważne” ze względu na lokalizację (prywatne mieszkanie). Zauważyła jak duży wpływ na kreowanie wizerunku mają sami archiwiści (jako miejsce specyficzne, niedostępne). Poddała analizie bardzo ciekawe zjawisko, którym jest funkcjonowanie archiwum prywatnego, ale publicznego, ogólnodostępnego w przestrzeni prywatnej. Archiwiści, którzy wywodzą się z archiwów domowych

10 Tamże.

11 D. Cooper, House proud. An ethnography of the BC Gay and Lesbian Archives, „Archival Science", 2016, nr 16, s. 261-288. 
(prywatnych) kwestionują sztywny podział między tym co publiczne a prywatne. Opiekunowi archiwum nie udało się zachować dystansu i obiektywizmu jak na archiwistę przystało. Właściciel mieszkania i jednocześnie opiekun archiwum nie był w stanie rozdzielić tych dwóch przestrzeni, co skutkowało niestabilnością zbiorów i ich niedostępnością. Wiążą się z tym również inne kwestie, jak sposób przechowywania, zabezpieczania zbiorów i ich udostępniania. Badania dały ciekawe spojrzenie na dotychczas pomijany problem funkcjonowania tego typu archiwów, tworzonych z potrzeby zachowywania historii tych ludzi, mimo społecznej marginalizacji. Autonomiczne, prywatne archiwa są dowodem na wykorzystanie różnych modeli archiwizacji, które mimo ciągle na pół-prywatnego charakteru, wychodzą do przestrzeni publicznej. Z kolei współpracująca $\mathrm{z}$ amerykańskimi instytucjami archiwistka i informatolożka Eunha (Anna) Youn ${ }^{12}$ starała się przedstawić problem wprowadzenia międzynarodowego standardu opisu archiwalnego ISAD $(G)$ w dwóch koreańskich archiwach. W swych badaniach również korzystała z metody etnograficznej. Wykorzystała ją do lepszego zrozumienia rozwoju systemu w szerokim kontekście koreańskiej polityki, społeczeństwa i historii. Jej główną motywacją do zastosowania tej metody było to, że tradycje archiwalne są wytworem złożonej mieszaniny historii, polityki, technologii i kultury. Są one nieuchronnie ustrukturyzowane lub ograniczone przez rozwój instytucjonalny i dlatego są istotne dla analizy systemu metadanych, a także analizy kulturowej instytucji, które studiowała. Metoda miała na celu identyfikację tradycji zarządzania archiwami w historii koreańskiej i zbadanie, w jaki sposób ewoluowały archiwa. Po przeprowadzonej analizie etnograficznej stwierdziła, że określone normy kulturowe i wartości organizacyjne były często osadzone w procesie przyjmowania ISAD(G). Mogły mieć silny wpływ na podejmowane decyzje, kierunki i metody z wdrażaniem standardu. Ponadto analiza ujawniła, że w Korei zainteresowanie opisem archiwalnym było zaskakująco niskie, szczególnie w zakresie jego zakresu i metod. Ustalono także, że pomysły przechowywania oryginalnych dokumentów, które powstały bezpośrednio poza biurokratyczną działalnością oraz zapewnienie publicznego dostępu do nich nie były częścią tradycyjnej koreańskiej praktyki archiwalnej ${ }^{13}$. Przez cały XX w. pomysł wykorzystania opisu do zwiększenia publicznego dostępu był uważany za niepotrzebny. Dopiero przyjęcie międzynarodowego standardu opisu przyniosło

12 E. Youn, Investigating Socio-cultural Aspects of the Implementation of an International Archival Descriptive Standard in Korea, [w:] Research in the Archival Multiverse, red. Anne J Gilliland, Sue McKemmish, Andrew J Lau, Clayton 2017, s. 789-810.

13 Tamże, s. 805. 
rewolucję w dotychczasowym myśleniu. Spowodowało przebudowę całego systemu archiwalnego badanych przez autorkę dwóch instytucji. Badania metodą etnograficzną pozwoliły dostrzec kulturę pracy w badanych archiwach. Jedna z badanych instytucji ma charakter bardziej strategiczny, badaczka spotkała się tam z dążeniem do ścisłego kontrolowania personelu w zakresie i zachowania, i wydajności pracy, tym samym hierarchia wewnątrz tej instytucji wywierała silny wpływ na pracę i zachowania personelu. Kultura organizacyjna tej instytucji opierała się na prestiżu, kontroli, autorytecie, pracy zespołowej, osobistych osiągnięciach, tolerancji, szacunku, zaangażowaniu. W drugiej z analizowanych instytucji z kolei zauważalna była większa autonomia pracowników. Powodowało to większą elastyczność i kreatywność, które wpływają pozytywnie na wydajność pracy. Autorka wspomniała także o trudnościach badawczych, są to przede wszystkim nieufność pracowników archiwów wobec badającego, ale także termin rozpoczęcia badań, intensywność i zaangażowanie, które mają ogromny wpływ na rezultaty. Ostatecznie uważa takie wieloaspektowe projekty badawcze niewątpliwie za ciekawsze, gdyż są w stanie ujawnić złożony charakter problematyki niż mogłoby to wynikać z badania używając tylko jednej metody ${ }^{14}$.

Spojrzeń na archiwum w szerszym, w tym przypadku etnograficznym, kontekście jest więcej. Archiwistka filmowa i informatolożka Karen Gracy ${ }^{15} \mathrm{z}$ Uniwersytetu w Pittsburghu (Pensylwania) chciała bliżej zrozumieć system pracy grupy pracowników archiwum zajmujących się konserwacją dokumentacji filmowej. W swoich badaniach terenowych najpierw obserwowała, potem wniknęła w środowisko, tak by poznać specyficzny język, którym operują konserwatorzy, ich metody pracy, zaangażowanie, a także relacje panujące między nimi. Aby dokonać dokładnej analizy potrzebowała wielu godzin obserwacji, rozmów i szczegółowych pytań. Autorka twierdzi, że zestaw metod jakościowych, które oferuje antropologia daje nowe możliwości dla badaczy do badania zjawisk w warunkach archiwalnych. Jest przekonana, że użyte przez nią metody są punktem wyjścia do zastosowania w projektowaniu nowych programów badawczych i rozwiązywaniu konkretnych problemów z domeny archiwalnej. Podkreśliła, że przyglądanie się pracy archiwistów dokumentacji filmowej może być trudne. Wydawać się może, że zarządzają materiałami w nielogiczny sposób, a zadaniem archiwisty jest przecież uporządkowanie dokumentacji w sposób jak najbardziej obiektywny. Zauważyła także, że program badań archiwalnych

14 Tamże, s. 808-810.

15 K.F. Gracy, Documenting Communities of Practice: Making the Case for Archival Ethnography, „Archival Science”, 2004, nr 4, s. 335-365. 
powoli dokonuje postmodernistycznego zwrotu. Wielu uczonych i praktyków zdaje się otwierać na inne metody badań w imię integracji teorii i praktyki, a także osiągnięcia celów związanych z zaufaniem i większym otwarciem na użytkowników ${ }^{16}$. Podkreśla przy tym, że z metody etnograficznej w badaniach instytucjonalnych (w tym przypadku archiwów) korzysta się bardzo rzadko, jej zdaniem przyczyną tego stanu rzeczy jest brak wyszkolenia w pracy tą metodą. Archiwiści w swoich badaniach zazwyczaj skłaniają się ku metodom historycznym, czasem korzystają z ankiet, nie daje im to jednak pełnego wglądu w problematykę. I chociaż archiwalne badania często odzwierciedlają zagadnienia procesów i funkcji, czego potwierdzeniem są liczne badania dotyczące opisywania praktyk, rzadko podchodzi się do tych samych tematów z perspektywy społeczno-kulturowej, które są z natury subiektywne, a więc sprzeczne $\mathrm{z}$,idealnym" modelem archiwalnego obiektywizmu ${ }^{17}$.

W Europie, na badania antropologiczne prowadzone w archiwum spojrzano nieco inaczej. Szwedzka badaczka zauważyła jak ważna jest analiza treści dokumentu z uwzględnieniem kontekstu kulturowo-historycznego, a więc antropologicznego. Rebecka Lennartsson ${ }^{18} \mathrm{w}$ swoich badaniach nad dziewiętnastowieczną prostytucją opublikowanych w 2012 r., potraktowała materiały archiwalne jako „teren badawczy” i w ten sposób starała się go eksplorować. Choć tamtego społeczeństwa już nie ma, to ślady, które zostały (pracowała m.in. na zeznaniach sądowych) pozwoliły jej poznać strukturę i zależności badanej grupy. Analizowała jakie materiały znalazły się w aktach sądowych, kto je zapisywał, jak je zapisywał (wyłapywała indywidualne cechy protokolantów), język jakim się posługiwano, świadków, kary jakie nakładano, kiedy uniewinniano. Odtwarzała całe procesy, dzięki materiałom archiwalnym, by móc je zinterpretować. W swych badaniach podkreśla jak ważna jest wyobraźnia i wrażliwość etnologa oraz otwartość na nieoczekiwane. Posługując się narzędziami dostarczonymi przez istniejące teorie, wraz z kontekstualizacją detali na poziomie indywidualnym, starała się rzucić nowe światło na związek między prawodawstwem, normami społecznymi i porządkiem władzy z jednej strony, a rolą jednostki z drugiej ${ }^{19}$.

W Polsce mniej więcej w tym samym czasie, gdy w krajach anglojęzycznych zaczęto publikować efekty pierwszych badań środowiska archiwum za

16 Tamże, s. 362.

17 Tamże.

18 R. Lennartsson, Archival Ethnography, or: Reflections on a Lost Note, „H-SozKult", 27.06.2012. https://www.hsozkult.de/debate/id/diskussionen-1813 (dostęp 20.03.2018).

19 Tamże. 
pomocą metod etnograficznych, uczeni zaczęli zwracać uwagę na możliwości zastosowania podejścia antropologicznego w archiwistyce. Refleksja teoretyczna rozwijała się zwłaszcza $\mathrm{w}$ dwóch środowiskach akademickich - toruńskim i radzyńsko-lubelsko-siedleckim. W 2004 r. Waldemar Chorążyczewski głosząc referat o integralności archiwistyki zwracał uwagę, że archiwa i archiwalia stanowią przedmiot zainteresowania nie tylko archiwistów-praktyków, archiwistów-teoretyków/archiwistyków, informatologów, zarządców dokumentacji, ale także kulturoznawców ujmujących archiwa i archiwalia jako fakty kulturowe ${ }^{20}$. W kolejnych swoich pracach zachęcał, by proponowane przez antropologów podejście - archiwa jako fenomeny cywilizacyjne - przyswoić archiwistyce ${ }^{21}$, w tamtym czasie badacz ten nie zwraca jednak uwagi na możliwą do przyswojenia metodologię, a jedynie nowy paradygmat myślenia.

W 2007 r. Chorążyczewski poddał kulturowej refleksji metodologię archiwistyki. Środowisko archiwistów/archiwistyków określił jako wioskę/kulturę w kontekście etnologicznym, którego zachowania w zakresie stosowania i zapożyczania metod badawczych poddał analizie, obejmującej badanie efektów działań tego środowiska w postaci prac naukowych. Doszedł do ogólnych wniosków dotyczących metod badawczych stosowanych w archiwistyce: „ludność wioski archiwistyków przybyła z wioski historyków. Ma ona skłonność do przyjmowania obyczajów wiosek sąsiednich, zwłaszcza bibliotekoznawców. Ci z kolei znajdują się pod przemożnym wpływem specjalistów od informacji i zarządzania. Szczególnie niektóre dzielnice wioski archiwistyków uległy wpływom bibliotekoznawców. Inne kierują wzrok raczej ku administratywistom. Dominuje wciąż jednak pamięć o związkach z wioską historyków"22. Autor posłużył się specyficznymi porównaniami odwołującymi się do terminologii i kategorii antropologicznych, w badaniach nie zastosował jednak metod etnograficznych. Podobne działania poczynił w 2004 r. Stanisław Roszak, historyk baroku i oświecenia, w rozprawie dotyczącej szlacheckich ksiąg silva rerum ${ }^{23}$ podjął świadomą metodologicznie próbę spojrzenia na archiwa jako zjawiska kulturowe. Wyszedł od pojęcia archiwum traktowanego nie tylko jako miejsce

20 W. Chorążyczewski, O archiwistykę integralną, „Klio”, t. 3, 2003, s. 150-158.

${ }^{21}$ Tenże, Archiwa i pamięć. $Z$ dziejów polskich archiwów, „Archiwa - Kancelarie Zbiory”, t. 1, red. W. Chorążyczewski, R. Degen, K. Syta, Toruń 2005.

${ }_{22}$ W. Chorążyczewski, Metodologia archiwistyki. Archiwistyka między nauką a refleksja, [w:] Toruńskie konfrontacje archiwalne, t. 1: Archiwistyka na uniwersytetach, archiwistyka $w$ archiwach, red. W. Chorążyczewski, A. Rosa, Toruń 2009, s. 191-201.

23 S. Roszak, Archiwa sarmackiej pamięci. Funkcje i znaczenie rękopiśmiennych ksiąg silva rerum $w$ kulturze Rzeczypospolitej XVIII wieku, Toruń 2004. 
przechowywania dokumentów, ale również jako miejsce konstruowania pamięci władzy. W badaniu odwołał się do kategorii kultury, jednak bez stosowania metod etnograficznych.

Równolegle na gruncie polskiej archiwistyki w literaturze zaczął być rozwijany nurt określony jako antropologizowanie archiwistyki/antropologizacja archiwum $^{24}$. To co w nim istotne i nowe to postawienie w centralnym punkcie refleksji teoretycznej, dotyczącej archiwum człowieka jako uczestnika kultury. Głównymi założeniami tego nurtu jest „uczłowieczanie” archiwum, postawienie i dostrzeganie w centrum procesów zachodzących w archiwum człowieka-archiwistę, ale też użytkownika/klienta archiwum, oraz twórcę dokumentacji z całym systemem jego wartości, potrzebami, zachowaniami, relacjami, osobowością, a dopiero w drugiej kolejności procesów zachodzących w archiwum dotyczących zagadnień związanych z gromadzeniem, kształtowaniem, rozmieszczeniem, porządkowaniem, opisywaniem, udostępnianiem czy popularyzacją archiwaliów ${ }^{25}$. Nurt ten daje zatem nowe możliwości w zakresie autorefleksji i samoświadomości archiwistów, inne możliwości badania źródeł i całości archiwalnych, a także inne podejście do użytkownika.

Wkrótce też Dariusz Magier definiując archiwozofię, nurt ten (antropologizowanie archiwistyki) uznał za jeden z jej obszarów badawczych. Samą archiwozofię, ogłaszając jednocześnie jako nowy dział archiwistyki, tuż obok teorii i metodyki archiwalnej, i archiwoznawstwa, zdefiniował jako filozofię archiwistyki, szeroko otwartą na nauki społeczne i z wyraźną perspektywą kulturową, uciekającą ku rozważaniom metaarchiwalnym, której przedmiotem jest idea archiwalna ${ }^{26}$. Z podejściem tym nie zgodził się Wojciech Piasek, który w 2013 r. ocenił dorobek antropologizującej się archiwistyki i rozważania dotyczące tego zjawiska ${ }^{27}$.

24 Zob. A. Rosa, O pożytkach z refleksji antropologicznej $w$ archiwistyce - funkcja edukacyjna archiwów, [w:] Toruńskie konfrontacje archiwalne, t. 1, s. 203-211; W. Chorążyczewski, Archiwista - Teoretyk? Archiwozof? Archiwistyk?, „Problemy Archiwistyki”, 2009, nr 3; tenże, Uwagi o przedmiocie i problematyce zantropologizowanej archiwistyki, [w:] Toruńskie konfrontacje archiwalne, t. 4: Nowa archiwistyka - archiwa i archiwistyka w ponowoczesnym kontekście kulturowym, red. W. Chorążyczewski, W. Piasek, A. Rosa, Toruń 2014, s. 25-35.

25 A. Rosa, Archiwa między historia i pamięcią. Antropologizowanie archiwistyki, [w:] „Archiwa - Kancelarie - Zbiory”, t. 2, red. W. Chorążyczewski, R. Degen, K. Syta, Toruń, 2008.

26 D. Magier, Czas archiwozofii, s. 9-20.

27 W. Piasek, „Nowa archiwistyka” - w stronę kulturowej teorii archiwum i archiwaliów, [w:] Toruńskie konfrontacje archiwalne, t. 4, s. 11-24. 
Nie do końca z uogólnieniami tych obu badaczy można się jednak zgodzić i nie chodzi o negację samej archiwozofii jako nowej dyscypliny naukowej w łonie archiwistyki, a o samo podejście kulturoznawcze/antropologiczne w archiwistyce, które jest po prostu swoistym paradygmatem, którym kierują się badacze tego typu model naukowego poznania stosujący. Przy czym na gruncie polskim model ten jest dopiero $\mathrm{w}$ fazie refleksji teoretycznej ${ }^{28}$. Nadal brakuje badań empirycznych w tym zakresie. Znakomitym i jedynym wyjątkiem są badania Magdaleny Wiśniewskiej-Drewniak zajmującej się archiwami społecznymi. W swoich badaniach stosuje ona strategię wielokrotnego studium przypadku z zastosowaniem metod wywiadu, obserwacji i analizy dokumentów zastanych. Raporty z badań terenowych publikuje w Internecie ${ }^{29}$, a ich analiza jest podstawą jej dysertacji ${ }^{30}$. Ponadto badaczka w jednym ze swych ostatnich artykułów zwróciła uwagę na możliwości wykorzystania terenowych badań jakościowych $\mathrm{w}$ badaniach związanych z zarządzaniem dokumentacją w instytucji ${ }^{31}$, co jest ciekawą propozycją metodologiczną dla tej dopiero co rozwijającej się dyscypliny, jeszcze poszukującej swojej tożsamości.

Do nurtu tego (antropologizującej archiwistyki, podejścia/paradygmatu kulturowego w archiwistyce) zaliczamy także prace, których podstawą jest metoda analizy egodokumentalnej, pozwalająca na wykorzystywanie teorii egodokumentu w badaniach całości archiwalnych ${ }^{32}$, kultury dokumentacyjnej czy archiwalnej w instytucji i całych systemach administracyjnych ${ }^{33}$. Istnieje już

${ }^{28}$ Zob. też badania dot. postrzegania archiwum przez białoruskich historyków uniwersyteckich za pomocą kategorii zaczerpniętych z antropologii kulturowej, A. Bialiauski, S. Zaharkewich, A. Prudnikow, Heurystyczna rola archiwum w kręgu białoruskich historyków profesjonalistów, [w:] Toruńskie konfrontacje archiwalne, t. 4, s. 189-203.

${ }_{29}$ Zob. Repozytorium Uniwersytetu Mikołaja Kopernika - RUMAK, raporty z badań M. Wiśniewskiej-Drewniak, https://repozytorium.umk.pl/handle/item/96/browse?value=Wi\%C5\%9Bniewska-Drewniak\%2C+Magdalena\&type=author (dostęp: 09.07.2018).

${ }_{30}$ M. Wiśniewska-Drewniak, Archiwa społeczne w Polsce - wielokrotne studium przypadku, praca doktorska napisana pod kierunkiem dr. hab. Waldemara, prof. UMK, publiczna obrona pracy doktorskiej odbyła się 29 maja 2018 r. na Wydziale Nauk Historycznych UMK w Toruniu, praca przechowywana w Archiwum UMK.

${ }^{31}$ Taż, Badanie zarządzania dokumentacją z użyciem metod empirycznych badań jakościowych, [w:] Zarządzanie dokumentacją. Badania i dydaktyka, red. R. Degen, M. Jabłońska, Toruń 2016, s. 77-94.

32 A. Rosa, Indywidualność twórcy archiwaliów a struktura zasobu archiwalnego, [w:] Zasada strukturalna jako podstawa opisu archiwaliów $w$ zintegrowanych systemach informacji archiwalnej, red. R. Leśkiewicz, A. Żeglińska, Warszawa, 2015, s. 33-41.

33 Zob. W. Chorążyczewski, A. Rosa, Egodokumenty - egodokumentalność - analiza egodokumentalna - spuścizna egodokumentalna, [w:] Egodokumenty. Tradycje historiograficzne i perspektywy badawcze, s. 11-22. 
szereg badań, których celem jest szukanie w przechowywanych w archiwach, archiwaliach, całych ich strukturach, cech osobowości autorów/twórców ${ }^{34}$. Osoby zajmujące się badaniami egodokumentalnymi w Polsce podchodzą do zagadnienia w bardzo różnorodny sposób, co świadczy o braku zakorzenienia samego terminu w tradycji polskich badań i ciągłym rozwoju. Łączy je natomiast jedno, wykorzystanie samoświadectw w badaniach antropologicznych, dzięki którym możliwe jest rekonstruowanie i interpretowanie oblicza danej kultury, grupy czy jednostki, której wytworem są archiwalia ${ }^{35}$.

Nurt ten na gruncie polskim w jego dojrzałej formie łączącej rozważania teoretyczne z badaniami empirycznymi dopiero zaczyna się rozwijać. Etnografia archiwalna daje jednak nową optykę, pozwala na spojrzenie, badanie i rozwiązywanie problemów pojawiających się w dziedzinie archiwalnej w inny sposób, nie od strony wytworu i struktur, ale twórcy i jego zależności w kulturze.

Przedstawione powyżej inne spojrzenia na archiwum potwierdzają rosnące zainteresowanie badaniem procesów zachodzących w nim od strony kulturowej i społecznej. Dzięki takim metodom można usprawnić wiele modeli funkcjonowania instytucji. Obserwacja dotyczyć może zarówno archiwistów, użytkowników, twórców dokumentacji, ale i samego dokumentu. Wartością dodaną tych metod, zwłaszcza etnografii archiwalnej jest jej wieloaspektowość. Nie zamyka się na analizę jednego problemu, a jej otwartość sprawia, że w trakcie prowadzonych badań dostrzegamy rzeczy, które wydawały nam się niewidoczne, bo „oczywiste”. Zebrany materiał z naturalnego otoczenia daje bardziej ugruntowane hipotezy oraz większe od innych prawdopodobieństwo sformułowania nowych. Jednak jak każda metoda i ta posiada wady, które badacz powinien brać pod uwagę. Materiał z terenu jest bardzo obszerny i trudny do zmierzenia. Do zrozumienia środowiska (w naszym przypadku instytucji, tworzących ją ludzi i badanego zagadnienia) niezbędna jest duża liczba godzin spędzonych na obserwacji. Nie jest możliwe zaobserwowanie wszystkich zachowań, stąd badacz już w pierwszej fazie dokonuje selekcji co brać pod uwagę, co pominąć. Obserwator staje się aktywnym uczestnikiem środowiska, co może wpłynąć na

34 Zob. W. Chorążyczewski, A. Rosa, Samoświadectwa pracowników polskiej kancelarii królewskiej czasów nowożytnych. Przypadek Jana Piotrowskiego, [w:] Polska kancelaria królewska między władzq̨ a społeczeństwem, cz. 4, red. W. Chorążyczewski, W. Krawczuk, Warszawa 2011, s. 87-106; A. Rosa, Elementy samoświadectwa personelu kancelaryjnego $w$ dokumentach $i$ księgach kancelarii koronnej, [w:] Polska kancelaria królewska między władzq a społeczeństwem, cz. 4, s. 73-85; K. Siuda, Życiorysy jako egodokumenty, [w:] Egodokumenty. Tradycje historiograficzne i perspektywy badawcze, s. 131-166.

35 Zob. np. A. Rosa, K. Siuda, Analiza egodokumentalna. 
obiektywizm zebranych danych. Obserwatorem jednak może być nie antropolog, ze względu na specyfikę badanego środowiska i jego język, a także umiejętność namierzania i definiowania występujących w tym środowisku problemów, nie sami archiwiści praktycy, a archiwistycy - archiwiści teoretycy.

Dzisiaj jesteśmy świadkami wielu inicjatyw: wprowadzania usprawnień dla użytkowników w archiwach, rozkwitu archiwów społecznych, podejmowania działań edukacyjnych i samego wychodzenia archiwów do społeczeństwa. Jest to bardzo dobry moment na podejmowanie badań antropologicznych w archiwum, które nie są oderwane od realiów, mają wypracowany warsztat metodologiczny i mogą zainspirować do pożądanych zmian, a także pokazać inne sposoby rozwiązywania w archiwach starych i nowych problemów.

\section{Bibliografia}

Bialiauski, Alieksandr, Sciepan Zaharkewich, Aleksander Prudnikow. „Heurystyczna rola archiwum w kręgu białoruskich historyków profesjonalistów". W Toruńskie konfrontacje archiwalne, t. 4: Nowa archiwistyka - archiwa i archiwistyka $w$ ponowoczesnym kontekście kulturowym, red. Waldemar Chorążyczewski, Wojciech Piasek, Agnieszka Rosa, 189-203. Toruń: Wydawnictwo Naukowe Uniwersytetu Mikołaja Kopernika, 2014.

Bonnain-Dulon Roland. „De l'apprentissage des archives pour une ethnologue (1974-2003)." Ateliers du LESC 32 (2008). https://doi.org/10.4000/ateliers.2732.

Borowska-Beszta, Beata. Etnografia dla terapeutów (pedagogów specjalnych) - szkice metodologiczne, Kraków: Oficyna Wydawnicza „Impuls”, 2005.

Burszta, Wojciech J., Michał Januszkiewicz. „Słowo wstępne: kłopot zwany kulturoznawstwem." W Kulturo-znawstwo: dyscyplina bez dyscypliny?, red. Wojciech J. Burszta, Michał Januszkiewicz, 7-21. Warszawa: Wydawnictwo Szkoły Wyższej Psychologii Społecznej „Academica”, 2010.

Chorążyczewski, Waldemar. „Archiwa i pamięć. Z dziejów polskich archiwów.” W Archiwa - Kancelarie - Zbiory, t. 1, red. Waldemar Chorążyczewski, Robert Degen, Krzysztof Syta, 13-27. Toruń, Wydawnictwo Uniwersytetu Mikołaja Kopernika, 2005.

Chorążyczewski, Waldemar. „Archiwista - Teoretyk? Archiwozof? Archiwistyk?”. Problemy Archiwistyki 3 (2009): 11-16. https://archiwa.gov.pl/images/docs/problemy/ WChorazyczewski_3.pdf.

Chorążyczewski, Waldemar. „Metodologia archiwistyki: archiwistyka między nauką a refleksją." W Toruńskie konfrontacje archiwalne, t. 1: Archiwistyka na uniwersytetach, archiwistyka w archiwach, red. Waldemar Chorążyczewski, Agnieszka Rosa, 191-202. Toruń: Wydawnictwo Naukowe Uniwersytetu Mikołaja Kopernika, 2009.

Chorążyczewski, Waldemar. „O archiwistykę integralną.” Klio 3 (2003): 150-158.

Chorążyczewski, Waldemar, Agnieszka Rosa. „Egodokumenty - egodokumentalność analiza egodokumentalna - spuścizna egodokumentalna." W Egodokumenty: tradycje historiograficzne i perspektywy badawcze, red. Waldemar Chorążyczewski, Arvydas 
Pacevicius, Stanisław Roszak, 11-22. Toruń, Wydawnictwo Naukowe Uniwersytetu Mikołaja Kopernika, 2015.

Chorążyczewski, Waldemar, Agnieszka Rosa. „Samoświadectwa pracowników polskiej kancelarii królewskiej czasów nowożytnych. Przypadek Jana Piotrowskiego." W Polska kancelaria królewska między władza a społeczeństwem, cz. 4, red. Waldemar Chorążyczewski, Wojciech Krawczuk, 87-106. Warszawa: Wydawnictwo DiG, 2011.

Chorążyczewski, Waldemar. „Uwagi o przedmiocie i problematyce zantropologizowanej archiwistyki." W Toruńskie konfrontacje archiwalne, t. 4: Nowa archiwistyka - archiwa $i$ archiwistyka $w$ ponowoczesnym kontekście kulturowym, red. Waldemar Chorążyczewski, Wojciech Piasek, Agnieszka Rosa, 25-35. Toruń: Wydawnictwo Naukowe Uniwersytetu Mikołaja Kopernika, 2014.

Cooper, Danielle. „House proud: an ethnography of the BC Gay and Lesbian Archives.” Archival Science 16, nr 3 (2016): 261-288. https://doi.org/10.1007/s10502-0159250-8.

Gracy, Karen F. „Documenting Communities of Practice: Making the Case for Archival Ethnography." Archival Science 4, nr 3-4 (2004): 335-365. https://doi.org/10.1007/ s10502-005-2599-3.

Kuper Adam. Kultura. Model antropologiczny. Przekł. Izabela Kołbon. Kraków: Wydawnictwo Uniwersytetu Jagiellońskiego, 2005.

Lennartsson, Rebecka. „Archival Ethnography, or: Reflections on a Lost Note.” H-Soz-Kult, 27.06.2012. https://www.hsozkult.de/debate/id/diskussionen-1813.

Magier, Dariusz. „Czas archiwozofii.” W Toruńskie konfrontacje archiwalne, t. 2: Teoria archiwalna - wczoraj - dziś - jutro, red. Waldemar Chorążyczewski, Agnieszka Rosa, 9-20. Toruń: Wydawnictwo Naukowe Uniwersytetu Mikołaja Kopernika, 2011.

Piasek, Wojciech. „Nowa archiwistyka - w stronę kulturowej teorii archiwum i archiwaliów." W Toruńskie konfrontacje archiwalne, t. 4: Nowa archiwistyka - archiwa $i$ archiwistyka $w$ ponowoczesnym kontekście kulturowym, red. Waldemar Chorążyczewski, Wojciech Piasek, Agnieszka Rosa, 11-24. Toruń: Wydawnictwo Naukowe Uniwersytetu Mikołaja Kopernika, 2014.

Rosa, Agnieszka. „Archiwa między historią i pamięcią: antropologizowanie archiwistyki.” W Archiwa - Kancelarie - Zbiory, t. 2, red. Waldemar Chorążyczewski, Robert Degen, Krzysztof Syta, 99-121. Toruń: Wydawnictwo Uniwersytetu Mikołaja Kopernika, 2008.

Rosa, Agnieszka. „Elementy samoświadectwa personelu kancelaryjnego w dokumentach i księgach kancelarii koronnej W Polska kancelaria królewska między władza a społeczeństwem, cz. 4, red. Waldemar Chorążyczewski, Wojciech Krawczuk, 73-85. Warszawa: Wydawnictwo DiG, 2011.

Rosa, Agnieszka. „Indywidualność twórcy archiwaliów a struktura zasobu archiwalnego.” W Zasada strukturalna jako podstawa opisu archiwaliów $w$ zintegrowanych systemach informacji archiwalnej, red. Rafał Leśkiewicz, Anna Żeglińska, 33-41. Warszawa: Instytut Pamięci Narodowej. Komisja Ścigania Zbrodni Przeciwko Narodowi Polskiemu, 2015.

Rosa, Agnieszka. „O pożytkach z refleksji antropologicznej w archiwistyce - funkcja edukacyjna archiwów." W Toruńskie konfrontacje archiwalne, t. 1: Archiwistyka na uniwer- 
sytetach, archiwistyka $w$ archiwach, red. Waldemar Chorążyczewski, Agnieszka Rosa, 203-211. Toruń: Wydawnictwo Naukowe Uniwersytetu Mikołaja Kopernika, 2009.

Rosa, Agnieszka, Kamila Siuda. „Analiza egodokumentalna pamiętników archiwistów jako przyczynek do poznania mentalności określonej grupy zawodowej." W Toruńskie konfrontacje archiwalne, t. 6: Pogranicza archiwistyki, red. Waldemar Chorążyczewski, Agnieszka Rosa. Toruń: Wydawnictwo Naukowe Uniwersytetu Mikołaja Kopernika, 2019 [w druku].

Roszak, Stanisław. Archiwa sarmackiej pamięci. Funkcje i znaczenie rękopiśmiennych ksiąg silva rerum w kulturze Rzeczypospolitej XVIII wieku. Toruń: Wydawnictwo Uniwersytetu Mikołaja Kopernika, 2004.

Shankar, Kalpana. „Recordkeeping in the Production of Scientific Knowledge: An Ethnographic Study." Archival Science 4, nr 3-4 (2004): 367-382. https://doi.org/10.1007/ s10502-005-2600-1.

Siuda, Kamila. „Życiorysy jako egodokumenty.” W Egodokumenty: tradycje historiograficzne i perspektywy badawcze, red. Waldemar Chorążyczewski, Arvydas Pacevicius, Stanisław Roszak, 131-166. Toruń, Wydawnictwo Naukowe Uniwersytetu Mikołaja Kopernika, 2015.

Wiśniewska-Drewniak, Magdalena. „Archiwa społeczne w Polsce - wielokrotne studium przypadku.” Praca doktorska, Uniwersytet Mikołaja Kopernika w Toruniu, 2018.

Wiśniewska-Drewniak, Magdalena, „Badanie zarządzania dokumentacją z użyciem metod empirycznych badań jakościowych." W Zarządzanie dokumentacją: badania i dydaktyka, red. Robert Degen, Marlana Jabłońska, 77-94. Toruń, Wydawnictwo Naukowe Uniwersytetu Mikołaja Kopernika, 2016.

Youn Eunha (Anna). „Investigating Socio-cultural Aspects of the Implementation of an International Archival Descriptive Standard in Korea." W Research in the Archival Multiverse, red. Anne J Gilliland, Sue McKemmish, Andrew J Lau, 789-810. Clayton: Monash University Publishing, 2017. 